\title{
Usefulness of Three under Exploited Vegetable Legumes - A Review
}

\author{
Prashant Kaushik $^{1^{*}}$, Shashi Kumar ${ }^{2}$ and M.S. Dhaliwal ${ }^{3}$ \\ ${ }^{1}$ Instituto de Conservación y Mejora de la Agrodiversidad Valenciana, Universitat Politècnica \\ de València, Camino de Vera 14, 46022, Valencia, Spain \\ ${ }^{2}$ International Center for Genetic Engineering and Biotechnology, Aruna Asaf Ali Marg, \\ New Delhi 110 067, India \\ ${ }^{3}$ Punjab Agricultural University, Ludhiana, Punjab, India \\ *Corresponding author
}

A B S T R A C T

Keywords

Exploited vegetable legumes, Portion

Article Info

Accepted:

10 February 2018

Available Online:

10 March 2018
Vegetables farm an important portion of human diet and are more important for the vegetarian population. Family Leguminosae is one of the highly diverse families of vegetables. In addition, vegetables belonging to this family are exceptionally rich in proteins, vitamins, minerals, and nutraceuticals. However, the vegetables belonging to this group were never exploited to the immense value they warrant. In this review, we highlight the usefulness of cultivating three underexploited vegetable legumes such as cluster bean, velvet bean and winged bean by discussing their botanical characters and health-related benefits.

\section{Introduction}

Leguminosae, also named as Fabaceae, is a big family of the dicotyledons flowering plants, with more than 18000 species further divided into 650 different genera. This family has tremendous potential for use of its members in numerous forms based on plant type, but still, the family is not well utilized (Young and Bharti, 2012; Varshney and Kudapa, 2013).

Most of the members of this family are annuals and cultivated for their fresh pods, foliage, tender shoots and roots, although they can be dried or processed for increasing their year-round availability (Rubatzky et al., 1997; Ntatsi et al., 2018). While some vegetable legumes like Pea and Phaseolus are popular and extensively cultivated in the world, others like Velvet Bean remain underexploited. This is based on the fact of their limited diversity, confinement to certain regions, (i.e. mostly to developing world), along with limited exploitation of their available resources on various scales to show the potential benefits of their use to the modern consumers (Fantz et al., 1991; O'Brian and Vance, 2007; Wyk and Boatwright, 2013). Nonetheless, vegetable legumes are highly rich in 
carbohydrates, oils, proteins, minerals, vitamins, micronutrients along with other important phytochemicals and bioactive compounds essentials for healthy life in order to overcome various cardiovascular and chronic diseases like cancer (Sandberg, 2002; Trinidad et al., 2009; Kaushik et al., 2015; Papandreou et al., 2018). In addition, these legumes are also acknowledged to have antinutritional factors harmful to human health like trypsin inhibitors, phytic acid etc, which further reduces their possible use as food and fodder. By employing different techniques like irradiation and fermentation, these toxins can be readily eliminated (D’Mello, 1992).

Although today's agriculture is dealing with the serious threat of climate change, vegetable legumes can reduce its harmful impact and provide global food security (Abelson, 1992; Smit et al., 1996). These underutilized vegetables are well adapted to climatic extremes and have a high tolerance of different stresses like drought and mineral deficiency; they have a broad genetic base due to the absence of human interference (Nagarajan and Nagarajan, 2010). Also, legumes are well known for their nodules, which can support nitrogen fixation and protect the soil from the harmful effect of erosion (Ampomah et al., 2012).

In this review, botanical, nutritional and breeding aspects of three vegetable legumes viz., cluster bean, velvet bean and the winged bean are examined for their numerous medicinal properties, which allow for multiple uses that research can discover.

\section{Botany}

Genus Cyamopsis include 3 species that are well distributed in Asia and Africa. These species are drought resistant and can sustain plant growth under extremely harsh climatic conditions. C. tetragonoloba (L.) Tabu. or
Guar bean $(2 \mathrm{n}=14)$ is a self-pollinated plant in nature and it is cultivated chiefly for its young pods; these can be cooked and dried to make industrial gum. Moreover, its seeds can also be used as fodder in both farms with or without pods (Patil, 2004; Purohit et al., 2011). C. tetragonoloba is an annual plant whose height ranges from $50-150 \mathrm{~cm}$ tall. Its other features include a taproot system, welldeveloped laterals, and rhizobium nodules. Its name comes from its pod's tendency to cluster together. The pod length varies from 32 to $110 \mathrm{~mm}$ with an average of around $58 \mathrm{~mm}$ in most of the refined varieties (Morris, 2010).

The species of genus Mucuna are identified to be trifoliate climbers. Pollination is carried out by bats and birds and as a result, they are known as zoophilous. With more than 100 species spread over various tropical and subtropical regions of the world, Мипсиа is divided into two subgenera, Mucuna and Stizolobium. While Mucuna pruriens (velvet bean) with $2 \mathrm{n}=22$ fits into subgenus Stizolobium, it can be clearly distinguished from other species within this genus based on the visual descriptors related to its seeds, fruit and corolla (Wilmot-Dear, 1991a, 1991b, 1993; Tozzi et al., 2005). Mucuna is a dualpurpose vegetable with pods consumed by humans and its tender leaves used as fodder for farm animals. Cultivated in some countries in the continents of Asia, America, and Africa, it has a tolerance to abiotic stresses like drought and high temperature. In contrast, it is susceptible to cold and frost. Morphologically the plant possesses dark brown pods covered with hairs and is typically around $10 \mathrm{~cm}$ long, with an average of four to six seeds inside (Lampariello et al., 2012).

Genus Psophocarpus Neck. ex DC consists of 10 species and grows wild in nature. This excludes $P$. tetragonolobus (winged bean), which is distributed in the tropics and 
popularly grown in some Asian countries (Klu, 2000). Although winged bean is a perennial plant with tuberous roots, it is generally cultivated as an annual. Every different part of its plant, (i.e., leaves, pods, seeds and tubers), is edible at every stage of its growth. Winged bean is also found to be resistant to soil acidity and salinity; thus, it can function as an excellent soil cover under those situations (Anugroho et al., 2015). It generally has four-cornered pods with wings of varying length and seed count on each corner (Nwokolo, 1996). Moreover, owing to its multipurpose nature as a plant, winged bean was introduced to eighty different countries, although it has been recently discovered that the cultivated winged bean has limited genetic diversity within popular varieties as the introduction of same common popular varieties (Chen et al., 2015).

\section{Nutritional importance}

\section{Cluster bean}

Cluster bean, when raised as a vegetable, is appreciable for its nutritional value, which consists of proteins, fat, carbohydrate, Vitamin A, Vitamin C, calcium and iron (Zanoni et al., 1980). However, it is also processed for its various commercial uses, such as the natural vegetable gum extracted from its endosperm. Originally it was grown as a green manure crop (Mudgil et al., 2011; Bhatt et al., 2016). Since its seed endosperm contains galactomannan, it is also known as an endosperm legume and is preferred as a food additive (Manjunath et al., 2016). Different natural compounds are present in the seeds of the cluster bean in the form of flavonoids like quercetin, kaempferol, phenolic compounds and tannins (Heyne and Whistler, 1948; Padalino et al., 2015).

In contrast, several unfavourable features were also reported in guar bean such as trypsin inhibitor (Hooper and Couch 1971), hemagglutinins (Arora and Joshi 1980), saponins (Curl et al., 1986), polyphenols (Kaushal and Bhatia 1982) and tannins. However, these components can be separated by various treatments via cooking or processing. Furthermore, health benefits of Guar bean consumption are numerous: low serum cholesterol levels, antidiabetic properties, and prevention of cardiovascular and cancerous diseases (Jenkins et al., 1975; Nishimura et al., 1997; Yellela et al., 2009; Kaczmarczyk et al., 2012). Moreover, the biopolymer obtained from the gaur gum can be utilized as for the removal of dissolved lead from the turbid industrial wastewater systems (Mukherjee et al., 2018).

\section{Velvet bean}

Velvet bean is a prominent source of different essential nutrients such as vitamins and minerals. As a result, it can be readily utilized as food and animal feed. It contains a high level of protein and serves as a supplement for humans (Pugalenthi et al., 2005; Bhat et al., 2008; Chikagwa-Malunga et al., 2009; Vadivel and Pugalenthi, 2010; Vadivel et al., 2011). Velvet bean possesses a phytochemical known as L-Dopa, which is a non-protein amino acid present in a higher concentration within its seed; it is used to treat Parkinson's disease (Kaizzi et al., 2006; Mannangatti and Naidu, 2016). Likewise, it is also found to be anti-cholesterol, antidiabetic, antitumor, aphrodisiac, anti-venom and antimicrobial in nature (Pugalenthi et al., 2005; Bhat et al., 2008; Chikagwa-Malunga et al., 2009; Vadivel and Pugalenthi, 2010b; Vadivel et al., 2011). However, one of the reasons that it is not a popular vegetable is that it isknown to contain several toxins such as tannins, lectins, phytic acid and trypsin inhibitors. Fortunately, these may vary in amount in each plant and they can be easily removed. Processes such as hydrothermal treatments, fermentation and 
ionising radiation-based processing can be used to remove the harmful compounds (Siddhuraju et al., 1996, 2000). Although in general, the constitution of these compounds is dependent on location, harvest processing and climate, along with many other factors (Pugalenthi et al., 2005).

\section{Winged bean}

Winged bean is identified to exhibit very high protein content as well as carbohydrates, fat and minerals. Subsequently, it can perhaps be recommended as infant food, for its dried seeds generally contains more than 30 percent protein while tuber contains up to 20 percent protein (Kadam and Salunkhe, 1984; Kantha and Erdman, 1984; Smith et al., 1984; Anugroho et al., 2015). Winged bean root tubers can also be cooked like potatoes. It is a surprisingly high yielder and can outperform many vegetables. Moreover, it is also one of the more heavily nodulated than some popular legumes (Nwokolo, 1996). Several studies have shown the Winged bean to be a powerful source of antioxidants, due to its phenolic content (Ismail et al., 2009; Khalili et al., 2013).

Winged bean also possesses antimicrobial properties against several human pathogenic microbes, which resulted in its use within traditional medicine in various parts of the world (Latha et al., 2006, 2008; Sasidharan et al., 2008a, 2008b). In contrast, there are several contaminants still present in winged bean namely; behenic acid, parinaric acid, trypsin inhibitors, phytic acid, tannin and lectin (de Lumen and Chan, 1986; Fernando and Bean, 1986; Kotaru et al., 1987). Yet, the trypsin inhibitors present in the winged bean are heat tolerant and require alternative methods for treatment like fermentation (Tan et al., 1983, 1984a, 1984b). Moreover, these anti-nutritional factors differ depending on different cultivars making it feasible to select beans with a lower content of these antinutritional factors (Fernando and Bean, 1985).

\section{Breeding aspects}

As self-pollination is a natural phenomenon in family Leguminosae, the cross-pollination is cumbersome. Furthermore, the specialised structures like a keel, small flowers and excessive flower drops also limit the chance of cross-pollination (Yang et al., 1990). The locally grown landraces can be integrated into the breeding programs for these vegetable legumes as they can contribute towards many desirable traits (Viswanatha et al., 2016). Wild relatives are more likely to assist in the genetic improvement of these legumes, but sometimes different kinds of genetic barriers limit their ability to achieve viable crosses (Tiffin et al., 2001). However, these genetic barriers can be overcome by specialized techniques like embryo rescue (Sharma, 1995; Sharma et al., 1996). Nevertheless, rapid plant regeneration protocols are also well studied and devised in these crops which can increase production time (Ahmad and Anis, 2015).

For these legumes the genetic variability is undoubtedly being of immense value for breeding and targeting several aspects like disease resistance and yield; as seen in their sister legumes that genetic variability facilitated to create germplasm for several uses and increased the adaptability of the plant to different environmental conditions (Harder, 1991). Moreover, there is the presence of an exceptional amount of diversity in these underexploited vegetable legumes for various plant morphological characters and biochemical parameters (Janardhanan et al., 2003). Knowledge of the inheritance patterns of these characters is a key for their successful genetic improvement and was also employed to revise them for various purposes. For example, in cluster 
bean, seven seed related quantitative characters were estimated among forty different genotypes and it was concluded that genetic variation was due to high additive effect and all the genotypes were grouped into seven different clusters irrespective of their place of collection (Pathak et al., 2011). Whereas, in winged bean one hundred twenty-one pure lines were isolated from the highlands of Papua New Guinea (Khan, 1976). Also, there is a wide intraspecific diversity present for various biochemical parameters pod parameters of velvet beans as studied in six distinct species (Adebowale et al., 2005).

Furthermore, various kinds of molecular markers were also employed to estimate diversity in Cluster bean, Velvet bean and Winged bean and shown a very high level of diversity even among morphologically similar lines (Capo-chichi et al., 2001; Chen et al., 2015; Kumar et al., 2015).

Mutation is known as a sudden heritable change in the genetic architecture of individual it can either be incorporated in the seeds or other vegetative plant parts (winged bean tubers) for these legumes mentioned in this review. Mutation can be induced by diverse means mainly by employing physical and chemical mutagen. However successful mutation should be free from undesirable changes and only have a target that is a trait of our interest (Donini and Sonnino, 1998). One of the traits of importance is the removal of undesirable phytochemicals like trypsin inhibitors e.g. in Winged bean using gamma rays and EMS (ethyl methane sulfonate) mutants were identified, lower in trypsin, chymotrypsin inhibitors and with low in tannins (Kothekar et al., 1996).

With the tremendous promises of the modern so-called genomic tools, it looks easier to perform breeding activities than to do the same by conventional breeding approaches. Likewise, with the rapid progress and cheap availability of sequencing technology, it can also establish as an important milestone for these underexploited legumes (Bohra et al., 2014). In fact, this technology has benefited various other legumes like chickpea, groundnut and pigeon pea. The draft genome sequence is helpful for accelerating plant breeding by pointing out easily the genes responsible for economically important traits. The transcriptomics, proteomics, metabolomics, and epigenomics have encouraged in various other crops and need a further detailed exploration to be applied to these underexploited vegetable legumes (Smýkal et al., 2014; Pandey et al., 2016). Traditional breeding methods to improve these crops can be complemented with genetic manipulation techniques to introduce genetic traits or event of interest e.g. Disease resistance, salt tolerance, insect pest resistance and biochemical compounds of interest at a very fast rate (Gosal et al., 2010).

These edible legumes are rich in essential fatty acids, proteins, vitamin and minerals but the overall production scenario of these legumes still lags. There is the continuous growing demand for plant-based proteins for humans and as well as livestock. Undoubtedly, these legumes can play a crucial role in diversifying agriculture and improving human health. However more farreaching research is needed to search for the possibilities of employing these under-utilized legumes as an integrated part of modern agricultural systems. Increased genetic resources both by indigenous and exotic resources are emphasized for increased and sustainable crop production of these three unexploited vegetable legumes. Moreover, these legumes can act as intercrop in our present horticultural system to combat insect pest infestation thereby increasing agricultural production and improving soil health. 


\section{References}

Abelson. 1992. Agriculture and Climate Change. Science, 9-9, https://doi.org/10.1126/science. 257.5066.9.

Adebowale, Y.., Adeyemi, and A.. Oshodi. 2005. Variability in the physicochemical, nutritional and antinutritional attributes of six Mucuna species. Food Chemistry, 37-48, https://doi. org/10.1016/j.foodchem.2004.01.084.

Adefegha, S., G. Oboh, S. Oyeleye, F. Dada, I. Ejakpovi, and A. Boligon. 2016. Cognitive Enhancing and Antioxidative Potentials of Velvet Beans (Mucuna pruriens) and Horseradish (Moringa oleifera) Seeds Extracts: A Comparative Study. Journal of Food Biochemistry, https://doi.org/10.1111/jfbc. 12292.

Ahmad, and Anis. 2015. Rapid plant regeneration protocol for cluster bean (Cyamopsis tetragonoloba L. Taub.). The Journal of Horticultural Science and Biotechnology, 585589, https://doi.org/10.1080/14620316. 2007.11512277.

Ampomah, O., E. James, P. Iannetta, G. Kenicer, J. Sprent, and K. Huss-Danell. 2012. Nodulation and ecological significance of indigenous legumes in Scotland and Sweden. Symbiosis, 57(3):133-148, https://doi.org/ 10.1007/s13199-012-0188-9.

Anugroho, F., M. Kitou, K. Kinjo, and N. Kobashigawa. 2015. Growth and Nutrient Accumulation of Winged Bean and Velvet Bean as Cover Crops in a Subtropical Region. Plant Production Science, 13(4):360-366, https://doi.org/10.1626/pps.13.360.

Bhat, R., K. Sridhar, and S. Seena. 2008. Nutritional quality evaluation of velvet bean seeds (Mucuna pruriens) exposed to gamma irradiation. International Journal of Food Sciences and Nutrition, 261-78,.

Bhatt, Jukanti, and Roy. 2016. Cluster bean [Cyamopsis tetragonoloba (L.) Taub.], an importantindustrial arid legume: A review. Legume Research - An International Journal, https://doi.org/10.18805/lr.v0iOF.11188.

Bohra, A., U. C. Jha, P. B. Kishor, S. Pandey, and N. P. Singh. 2014. Genomics and molecular breeding in lesser explored pulse crops: current trends and future opportunities. Biotechnology
Advances, 32(8):1410-28, https://doi.org/10. 1016/j.biotechadv.2014.09.001.

Capo-chichi, Weaver, and Morton. 2001. AFLP assessment of genetic variability among velvet bean (Mucuna sp.) accessions. TAG Theoretical and Applied Genetics, 1180-1188, https://doi.org/10.1007/s001220100722.

Chel-Guerrero, L., S. Galicia-Martínez, J. Acevedo-Fernández, J. Santaolalla-Tapia, and D. Betancur-Ancona. 2016. Evaluation of Hypotensive and Antihypertensive Effects of Velvet Bean (Mucuna pruriens L.) Hydrolysates. Journal of Medicinal Food.

Chen, D., X. Yi, H. Yang, H. Zhou, Y. Yu, Y. Tian, and X. Lu. 2015. Genetic diversity evaluation of winged bean (Psophocarpus tetragonolobus (L.) DC.) using inter-simple sequence repeat (ISSR). Genetic Resources and Crop Evolution, 62(6):823-828, https://doi.org/10.1007/s10722-015-0261-3.

Chikagwa-Malunga, S. K., A. T. Adesogan, L. E. Sollenberger, S. C. Phatak, N. J. Szabo, S. C. Kim, C. M. Huisden, and R. C. Littell. 2009. Nutritional characterization of Mucuna pruriens 4 . Does replacing soybean meal with Mucuna pruriens in lamb diets affect ruminal, blood and tissue 1-dopa concentrations? Animal Feed Science and Technology, 124-137, https://doi.org/10.1016/j.anifeedsci.2008.03.00 3.

D'Mello, J. P. F. 1992. Chemical constraints to the use of tropical legumes in animal nutrition. Animal Feed Science and Technology, 237261, https://doi.org/10.1016/0377-8401 (92)90 $105-\mathrm{F}$.

De Lumen, and Chan. 1986. Antinutritional and biochemical properties of winged bean trypsin inhibitors. Advances in Experimental Medicine and Biology, 413-27.

Donini, and Sonnino. 1998. Somaclonal Variation and Induced Mutations in Crop Improvement. 255-291 pp. https://doi.org/10.1007/978-94015-9125-6_14.

Fantz, P., Stirton, and Zarucchi. 1991. Advances in Legume Biology. Systematic Botany, 584, https://doi.org/10.2307/2419344.

Fernando, T., and G. Bean. 1985. Variation of the anti-nutritional behenic acid content among the cultivars of winged bean (Psophocarpus tetragonolobus L. DC). Food Chemistry, 
18(4):265-269, https://doi.org/10.1016/03088146 (85)90107-4.

Fernando, T., and G. Bean. 1986. The reduction of antinutritional behenic acid in winged bean (Psophocarpus tetragonolobus L. DC) seeds. Qualitas Plantarum Plant Foods for Human Nutrition, 93-96, https://doi.org/10.1007/ BF01092136.

Gosal, S., S. Wani, and M. Kang. 2010. Biotechnology and Crop Improvement. Journal of Crop Improvement, 153-217, https://doi.org/10.1080/15427520903584555.

Harder, D. 1991. Grain Legumes: Evolution and Genetic Resources Joseph Smartt. Press Syndicate of the Cambridge University Press, Cambridge. 1990. 379 pp. ISBN 0-521-30797 $\mathrm{x}$. Price $\$ 90$ (cloth). Biochemical Systematics and Ecology, 178-179, https://doi.org/ 10.1016/0305-1978 (91)90045-2.

HEYNE, E., and R. L. WHISTLER. 1948. Chemical composition and properties of guar polysaccharides. Journal of the American Chemical Society, 70(6):2249-52.

Ismail, A., N. Tiong, S. Tan, and A. Azlan. 2009. Antioxidant properties of selected non- leafy vegetables. Nutrition \& Food Science, 176180 ,

https://doi.org/10.1108/00346650910943280.

Janardhanan, Vadivel, and Pugalenthi. 2003. Improvement Strategies of Leguminosae Biotechnology. 353-405, https://doi.org/10. 1007/978-94-017-0109-9_17.

Jenkins, D.., C. Newton, A. Leeds, and J. Cummings. 1975. EFFECT OF PECTIN, GUAR GUM, AND WHEAT FIBRE ON SERUM-CHOLESTEROL. The Lancet, 11161117, https://doi.org/10.1016/S0140-6736 (75)92503-9.

Kaczmarczyk, M., M. Miller, and G. Freund. 2012. The health benefits of dietary fiber: beyond the usual suspects of type 2 diabetes mellitus, cardiovascular disease and colon cancer. Metabolism: Clinical and Experimental, 1058-66, https://doi.org/ 10.1016/j.metabol.2012.01.017.

Kadam, and Salunkhe. 1984. Winged bean in human nutrition. Critical Reviews in Food Science and Nutrition, 1-40.

Kaizzi, C., H. Ssali, and P. Vlek. 2006. Differential use and benefits of Velvet bean (Mucuna pruriens var. utilis) and $\mathrm{N}$ fertilizers in maize production in contrasting agroecological zones of E. Uganda. Agricultural Systems, 44-60, https://doi.org/10.1016/j.agsy.2005.06.003.

Kantha, S., and J. Erdman. 1984. The winged bean as an oil and protein source: A review. Journal of the American Oil Chemists' Society, 61(3):515-525, https://doi.org/10.1007/bf02 677021.

Kaushik, P., I. Andújar, S. Vilanova, M. Plazas, P. Gramazio, F. Herraiz, N. Brar, and J. Prohens. 2015. Breeding Vegetables with Increased Content in Bioactive Phenolic Acids. Molecules, 18464-18481, https://doi.org/ 10.3390/molecules201018464.

Khalili, M., E. Shafekh, A. H. Norhayati, M. Fatahudin, Rahimah, Norkamalia, and N. Azimah. 2013. Total Phenolic Content and In vitro Antioxidant Activity of Winged Bean (Psophocarpus tetragonolobus). Pakistan Journal of Nutrition, 416-422, https://doi.org/10.3923/pjn.2013.416.422.

Khan. 1976. Papua New Guinea: A centre of genetic diversity in winged bean (Psophocarpus tetragonologus (L.) Dc.). Euphytica, 25(1):693-705, https://doi.org/ $10.1007 / \mathrm{bf00041608.}$

Klu, G. 2000. Induced mutation for accelerated domestication: a case study of winged bean (Psophocarpus tetragonolobus (L.) DC). West African Journal of Applied Ecology, 1.

Kotaru, M., T. Ikeuchi, H. Yoshikawa, and F. Ibuki. 1987. Investigations of antinutritional factors of the winged bean (Psophocarpus tetragonolobus). Food Chemistry, 279-286, https://doi.org/10.1016/0308-8146 (87)901038.

Kothekar, V., A. Harsulkar, and A. Khandelwal. 1996. Low Trypsin and Chymotrypsin Inhibitor Mutants in Winged Bean (Psophocarpus tetragonolobus (L) DC). Journal of the Science of Food and Agriculture, 137-140, https://doi.org/ 10.1002/(SICI)1097-0010(199605) 71:1<137: :AID-JSFA563>3.0.CO;2-Y.

Kumar, S., M. Parekh, C. Patel, H. Zala, R. Sharma, K. Kulkarni, R. Fougat, R. Bhatt, and A. Sakure. 2015. Development and validation of EST-derived SSR markers and diversity analysis in cluster bean (Cyamopsis tetragonoloba). Journal of Plant Biochemistry 
and Biotechnology, https://doi.org/10.1007/ s13562-015-0337-3.

Lampariello, L., A. Cortelazzo, R. Guerranti, C. Sticozzi, and G. Valacchi. 2012. The Magic Velvet Bean of Mucuna pruriens. Journal of Traditional and Complementary Medicine, 2(4):331-9, https://doi.org/10.1016/S22254110 (16)30119-5.

Latha, Y., Sasidharan, Zuraini, Suryani, Shirley, and Sangetha. 2008. Antibacterial Activity and Toxicity of Psophocarpus tetragonolobus. Pharmaceutical Biology, 31-36, https://doi.org/10.1080/13880200601026317.

Latha, Y., Sasidharan, Zuraini, Suryani, Shirley, Sangetha, and Davaselvi. 2006. Antimicrobial activities and toxicity of crude extract of the Psophocarpus tetragonolobus pods. African Journal of Traditional, Complementary, and Alternative Medicines: AJTCAM / African Networks on Ethnomedicines, 59-63, https://doi.org/10.4314/ajtcam.v4i1.31195.

Manjunath, Anjali, Gowda, P. Kumar, A. Srivastava, R. Osmani, C. Shinde, and Siddaramaiah. 2016. Guar Gum and Its Pharmaceutical and Biomedical Applications. Advanced Science, Engineering and Medicine, 589-602(14), https://doi.org/10.1166/asem. 2016.1874.

Mannangatti, P., and K. Naidu. 2016. Indian Herbs for the Treatment of Neurodegenerative Disease. Advances in Neurobiology, 323-36, https://doi.org/10.1007/978-3-319-283838_17.

Morris. 2010. Morphological and reproductive characterization of guar (Cyamopsis tetragonoloba) genetic resources regenerated in Georgia, USA. Genetic Resources and Crop Evolution, 57(7):985-993, https://doi.org/ 10.1007/s10722-010-9538-8.

Mudgil, D., S. Barak, and B. Khatkar. 2011. Guar gum: processing, properties and food applications-A Review. Journal of Food Science and Technology, 51(3):409-18, https://doi.org/10.1007/s13197-011-0522-x.

Mukherjee, S., S. Mukhopadhyay, M. Zafri, X. Zhan, M. Hashim, and B. Gupta. 2018. Application of guar gum for the removal of dissolved lead from wastewater. Industrial Crops and Products, 261-269, https://doi.org/10.1016/j.indcrop.2017.10.022.
Nagarajan, S., and S. Nagarajan. 2010. Abiotic Stress Adaptation in Plants. https://doi.org/ 10.1007/978-90-481-3112-9_1.

NISHIMURA, N., K. TOMINAGA, and S. KIRIYAMA. 1997. Relationship between Plasma Cholesterol-Lowering Effect of Guar Gum and Its Cecal Fermentation Products in Rats. Nippon Eiyo Shokuryo Gakkaishi, 429437, https://doi.org/10.4327/jsnfs.50.429.

Ntatsi, G., M. Gutiérrez-Cortines, I. Karapanos, A. Barros, J. Weiss, A. Balliu, E. dos Rosa, and D. Savvas. 2018. The quality of leguminous vegetables as influenced by preharvest factors. Scientia Horticulturae, 191-205, https://doi.org/10.1016/j.scienta. 2017.12.058.

Nwokolo. 1996. Food and Feed from Legumes and Oilseeds. 173-181 pp. https://doi.org/ 10.1007/978-1-4613-0433-3_17.

O'Brian, and Vance. 2007. Legume Biology: Sequence to Seeds. PLANT PHYSIOLOGY, 537-537, https://doi.org/10.1104/pp.104. 900226.

Padalino, L., M. Mastromatteo, L. Lecce, S. Spinelli, A. Conte, and M. A. Del Nobile. 2015. Optimization and characterization of gluten-free spaghetti enriched with chickpea flour. International Journal of Food Sciences and Nutrition, 66(2):148-58, https://doi.org/ 10.3109/09637486.2014.959897.

Pandey, M., M. Roorkiwal, V. Singh, A. Ramalingam, H. Kudapa, M. Thudi, A. Chitikineni, A. Rathore, and R. Varshney. 2016. Emerging Genomic Tools for Legume Breeding: Current Status and Future Prospects. Frontiers in Plant Science, 7:455, https://doi.org/10.3389/fpls.2016.00455.

Papandreou, C., N. Becerra-Tomás, M. Bulló, M. Á. Martínez-González, D. Corella, R. Estruch, E. Ros, F. Arós, H. Schroder, M. Fitó, L. Serra-Majem, J. Lapetra, M. Fiol, M. RuizCanela, J. V. Sorli, and J. Salas-Salvadó. 2018. Legume consumption and risk of all-cause, cardiovascular, and cancer mortality in the PREDIMED study. Clinical Nutrition (Edinburgh, Scotland), https://doi.org/ 10.1016/j.clnu.2017.12.019.

Pathak, R., M. Singh, and Henry. 2011. Genetic diversity and interrelationship among clusterbean (Cyamopsis tetragonoloba) 
genotypes for qualitative traits. Indian Journal of Agricultural Sciences, 81.

Patil, C. 2004. Nuclear DNA Amount Variation in Cyamopsis D.C. (Fabaceae). CYTOLOGIA, 69(1):59-62,

https://doi.org/10.1508/cytologia.69.59.

Pugalenthi, Vadivel, and Siddhuraju. 2005. Alternative food/feed perspectives of an underutilized legume Mucuna pruriens var. utilis--a review. Plant Foods for Human Nutrition (Dordrecht, Netherlands), 60(4):201-18.

Purohit, J., A. Kumar, M. Hynniewta, and R. Satyawada. 2011. Karyomorphological Studies in Guar (Cyamopsis tetragonoloba (Linn.) Taub.) - An Important Gum Yielding Plant of Rajasthan, India. CYTOLOGIA, 76(2):163169, https://doi.org/10.1508/cytologia.76.163.

Rubatzky, V., M. Yamaguchi, V. Rubatzky, and M. Yamaguchi. 1997. World Vegetables. 3-16, https://doi.org/10.1007/978-1-4615-6015-9_1.

Sandberg, A.-S. 2002. Bioavailability of minerals in legumes. The British Journal of Nutrition, S281-5, https://doi.org/10.1079/BJN/2002718.

Sasidharan, Zuraini, Y. Latha, and Suryani. 2008a. Fungicidal Effect and Oral Acute Toxicity of Psophocarpus tetragonolobus. Root Extract. Pharmaceutical Biology, 261265, https://doi.org/10.1080/13880200701740 858.

Sasidharan, Zuraini, Y. Latha, Sangetha, and Suryani. 2008b. Antimicrobial activities of Psophocarpus tetragonolobus (L.) DC extracts. Foodborne Pathogens and Disease, 303-9, https://doi.org/10.1089/fpd.2007.0078.

Sharma, Kaur, and Kumar. 1996. Embryo rescue in plants-a review. Euphytica, 325-337, https://doi.org/10.1007/BF00022289.

Sharma. 1995. How wide can a wide cross be? Euphytica, 43-64, https://doi.org/10.1007/ BF00028709.

Siddhuraju, Becker, and Makkar. 2000. Studies on the nutritional composition and antinutritional factors of three different germplasm seed materials of an under-utilized tropical legume, Mucuna pruriens var. utilis. Journal of Agricultural and Food Chemistry, 48(12):6048-60.

Siddhuraju, P., K. Vijayakumari, and K. Janardhanan. 1996. Chemical Composition and Protein Quality of the Little-Known Legume,
Velvet Bean (Mucuna pruriens (L.) DC.). Journal of Agricultural and Food Chemistry, 44(9):2636-2641, https://doi.org/10.1021/jf950776x.

Smit, McNabb, and Smithers. 1996. Agricultural adaptation to climatic variation. Climatic Change, 7-29, https://doi.org/10.1007/BF00140511.

Smith, O. B., J. O. Ilori, and Onesirosan. 1984. The proximate composition and nutritive value of the winged bean Psophocarpus tetragonolobus (L.) DC for broilers. Animal Feed Science and Technology, 231-237, https://doi.org/10.1016/0377-8401 (84)90066$\mathrm{X}$.

Smýkal, P., C. Coyne, M. Ambrose, N. Maxted, H. Schaefer, M. Blair, J. Berger, S. Greene, M. Nelson, N. Besharat, T. Vymyslický, C. Toker, R. Saxena, M. Roorkiwal, M. Pandey, J. Hu, Y. Li, L. Wang, Y. Guo, L. Qiu, R. Redden, and R. Varshney. 2014. Legume Crops Phylogeny and Genetic Diversity for Science and Breeding. Critical Reviews in Plant Sciences, 34(1-3):43-104, https://doi.org/10. 1080/07352689.2014.897904.

Tan, N., K. Wong, and B. Lumen. 1984a. Relationship of tannin levels and trypsin inhibitor activity with the in vitro protein digestibilities of raw and heat-treated winged bean (Phosphocarpus tetragonolobus). Journal of Agricultural and Food Chemistry, 819-822, https://doi.org/10.1021/jf00124a030.

Tan, N., Z. Rahim, H. Khor, and K. Wong. 1983. Winged bean (Psophocarpus tetragonolobus) tannin level, phytate content and hemagglutinating activity. Journal of Agricultural and Food Chemistry, 916-917, https://doi.org/10.1021/jf00118a063.

Tan, N., Z. Rahim, H. Khor, and K. Wong. 1984b. Chymotrypsin inhibitor activity in winged beans (Psophocarpus tetragonolobus). Journal of Agricultural and Food Chemistry, 163-166, https://doi.org/10.1021/jf00121a038.

Tiffin, Olson, and Moyle. 2001. Asymmetrical crossing barriers in angiosperms. Proceedings of the Royal Society of London B: Biological Sciences, 861-867, https://doi.org/10.1098/ rspb.2000.1578.

Tozzi, A., K. Agostini, and M. Sazima. 2005. A New Species of MucunaAdans. (Leguminosae, Papilionoideae, Phaseoleae) from Southeastern 
Brazil, with a Key to Brazilian Species. Taxon, 451, https://doi.org/10.2307/25065372.

Trinidad, T., A. Mallillin, A. Loyola, R. Sagum, and R. Encabo. 2009. The potential health benefits of legumes as a good source of dietary fibre. The British Journal of Nutrition, 569-74, https://doi.org/10.1017/s0007114509992157.

Vadivel, and Pugalenthi. 2010b. Evaluation of growth performance of broiler birds fed with diet containing different levels of velvet bean meal as an alternative protein ingredient. Livestock Science, 76-83, https://doi.org/ 10.1016/j.livsci.2009.09.002.

Vadivel, Pugalenthi, Doss, and Parimelazhagan. 2011. Evaluation of velvet bean meal as an alternative protein ingredient for poultry feed. Animal: An International Journal of Animal Bioscience, 67-73, https://doi.org/10.1017/ s175173111000159x.

Vadivel, V., and H. Biesalski. 2012. Bioactive Compounds in Velvet Bean Seeds: Effect of Certain Indigenous Processing Methods. International Journal of Food Properties, 1069-1085, https://doi.org/10.1080/1094291 2.2010 .513466$.

Vadivel, V., and M. Pugalenthi. 2010a. Studies on the incorporation of velvet bean (Mucuna pruriens var. utilis) as an alternative protein source in poultry feed and its effect on growth performance of broiler chickens. Tropical Animal Health and Production, 1367-76, https://doi.org/10.1007/s11250-010-9594-2.

Varshney, R., and H. Kudapa. 2013. Legume biology: the basis for crop improvement. Functional Plant Biology, v-viii, https://doi.org/10.1071/FPv40n12_FO.

Viswanatha, Yogeesh, and Amitha. 2016. Morphological diversity study in horsegram (Macrotylomauniflorum (Lam.) Verdc) based on Principal Component Analysis (PCA). Electronic Journal of Plant Breeding, 7.

Wilmot-Dear. 1991a. A Revision of Mucuna (Leguminosae-Phaseoleae) in the Philippines. Kew Bulletin, 213, https://doi.org/10.2307/ 4110591.

Wilmot-Dear. 1991b. MucunahainanensisHayata subsp. multilamellata Wilmot-Dear: A New Name for a Long-Known Taxon (Leguminosae: Phaseoleae) and a Key to Related Species. Kew Bulletin, 205, https://doi.org/10.2307/4110590.

Wilmot-Dear. 1993. A New Species of Mucuna (Leguminosae-Phaseoleae) from Thailand, and a Revised Key to the Species in Thailand, Indochina and the Malay Peninsula. Kew Bulletin, 29, https://doi.org/10.2307/4115745.

Wyk, B.-E., and Boatwright. 2013. Advances in legume systematics 12. South African Journal of Botany, 1-2, https://doi.org/10.1016/ j.sajb.2013.08.001.

Yang, Yan, and Zhou. 1990. Legumes and Oilseed Crops I. https://doi.org/10.1007/978-3642-74448-8_22.

Yellela, S, and R. 2009. Guar gum- based colon- specific drug delivery systems for the treatment of Inflammatory Bowel Diseases: P- 0166. Inflammatory Bowel Diseases, S56, https://doi.org/10.1097/00054725-20091200200175.

Young, N., and A. Bharti. 2012. Genome-enabled insights into legume biology. Annual Review of Plant Biology, 283-305, https://doi.org/ 10.1146/annurev-arplant-042110-103754.

Zanoni, T., R. Whistler, and T. Hymowitz. 1980. Guar: Agronomy, Production, Industrial Use, and Nutrition. Soil Science, 107, https://doi. org/10.1097/00010694-198008000-00011.

\section{How to cite this article:}

Prashant Kaushik, Shashi Kumar and Dhaliwal, M.S. 2018. Usefulness of Three under Exploited Vegetable Legumes - A Review. Int.J.Curr.Microbiol.App.Sci. 7(03): 861-870. doi: https://doi.org/10.20546/ijcmas.2018.703.101 